\title{
Perspektywa feministyczna w badaniach nad terroryzmem
}

\begin{abstract}
Streszczenie: Celem artykułu jest analiza problemu terroryzmu poprzez pryzmat założeń zróżnicowanej teorii feminizmu, zaliczanej do podejść postpozytywistycznych. Hipotezą artykułu jest przypuszczenie, że badanie terroryzmu z wykorzystaniem teorii feminizmu pozwala poszerzyć zakres jego analizy oraz skonstatować, że to zjawisko ma szerokie uwarunkowania kulturowe i społeczne, a nawet biologiczne, które kształtują jego genezę, strukturę, funkcjonowanie i konsekwencje. Ujęcie feministyczne umożliwia pełniejszą analizę motywów podejmowania i sposobów prowadzenia działalności terrorystycznej przez kobiety, a tym samym pozwala wykazać specyfikę terroryzmu kobiecego. Przyjęte podejście jest charakterystyczne dla gender studies. Koncentruje się na dostrzeganiu różnic i podobieństw między mężczyznami a kobietami, które są wytworem życia społecznego. Zakłada się przy tym, że status społeczny oraz role i możliwości kobiet są zjawiskami relacyjnymi, które wyznaczane są w odniesieniu do statusu, pozycji i ról społecznych mężczyzn. Teoria feminizmu może być wykorzystana do analizy terroryzmu, ze względu na to, że skupia się na badaniach na poziomie jednostki, kobiety i mężczyzny. Różnica płci jako zmiennej konstytuującej rzeczywistość społeczną ma więc kluczowe znaczenie w badaniu terroryzmu. W konkluzji artykułu autorka stwierdza, że kobiety są obecne w organizacjach terrorystycznych i dlatego ich udział winien być badany, a użyteczną do tego metodologią jest podejście wypracowane przez teorie feministyczne.
\end{abstract}

Słowa kluczowe: badania nad terroryzmem, feminizm, gender, postpozytywizm, przestępczość kobiet

\section{Wprowadzenie}

$\mathbf{W}$ ybór tematyki terroryzmu w perspektywie teorii feministycznej podyktowany jest współczesnym postrzeganiem tego zjawiska oraz intepretowaniem zarówno w dyskursie naukowym, jak i debacie publicznej. Przed wydarzeniami z 11 września 2001 roku terroryzm był badany przede wszystkim na gruncie nauk o polityce i socjologii. Po zamachach na World Trade Center i Pentagon problematyka studiów nad terroryzmem prezentowana jest nie tylko $\mathrm{w}$ ramach nauk o polityce, ale $\mathrm{w}$ szerokim zakresie w naukach o bezpieczeństwie, naukach prawnych, psychologii, antropologii, czy kulturoznawstwie. Eskalacja terroryzmu i nowe wyzwania z tym związane, w tym partycypacja kobiet we wszystkich współczesnych nurtach terrorystycznych, tworzą potrzebę przedefiniowania tradycyjnego pojmowania terrorysty, jako mężczyzny.

Celem artykułu jest analiza problemu terroryzmu poprzez pryzmat założeń zróżnicowanych wewnętrznie teorii feminizmu. Ukazane zatem będą związki pomiędzy feminizmem a bezpieczeństwem, a właściwie relacje między feminizmem a zagrożeniem bezpieczeństwa poprzez terroryzm. To pozwoli na końcu sformułować wnioski ukazujące specyfikę terroryzmu kobiecego. Można przyjąć założenie, że w badaniach nad przemocą polityczną, a w szczególności nad terroryzmem, dominują przypisane płci stereotypy i znaczenia wpisujące się w tzw. męskie spojrzenie, które preferuje nierówny podział 
uprawnień, marginalizując kobiety. Stąd teorie feministyczne mogą być stosowane do poszerzenia analizy tego zjawiska. Hipotezą artykułu jest przypuszczenie, że badanie zjawiska terroryzmu $\mathrm{z}$ wykorzystaniem teorii feminizmu pozwala poszerzyć zakres jego analizy oraz skonstatować, że to zjawisko ma szerokie uwarunkowania kulturowe i społeczne, a nawet biologiczne, które kształtują jego genezę, strukturę, funkcjonowanie i konsekwencje. Ujęcie feministyczne umożliwia pełniejszą analizę motywów podejmowania i sposobów prowadzenia działalności terrorystycznej przez kobiety, a tym samym pozwala wykazać odmienność terroryzmu kobiecego. Podejście przyjęte w artykule jest charakterystyczne dla gender studies. Koncentruje się na dostrzeganiu różnic i podobieństw między mężczyznami a kobietami, które są wytworem życia społecznego. Zakłada się przy tym, że status społeczny i role oraz możliwości kobiet są zjawiskiem relacyjnym, które wyznaczane są w odniesieniu do statusu, pozycji i ról mężczyzn w danej przestrzeni.

Płaszczyzną analizy jest terroryzm jako rodzaj przemocy stosowanej od wieków przez jednostki i zorganizowane grupy, a nawet państwa, do osiagania celów politycznych. Terroryzm rozumiany jest jako forma radykalnej przemocy politycznej, podejmowanej z premedytacja, celem wywołania klimatu ekstremalnego strachu. Nastawiona na wpływanie na szerszą społeczność niż ofiary bezpośredniej przemocy, co często powoduje przypadkowy dobór miejsca ataku (często symbolicznego) i ofiar oraz jest wykorzystywane w celu zademonstrowania sprzeciwu wobec społeczności, w której atak został dokonany. Bestialstwo ataku pełni funkcję kreacyjną oburzenia i strachu, a niekiedy funkcję odwetową (Wilkinson, 1996, s. 3). Upraszczając można stwierdzić, że terroryzm jest działaniem na audytorium za pomocą siły lub przemocy wobec osób lub mienia w celu zastraszenia/wywarcia przymusu na rząd i/lub ludność cywilną. Wobec tego termin „terroryzm” może być ujmowany jak metoda działania, której psychologicznym efektem ma być wywoływanie terroru (Jenkins, 1975; Gibbs, 1989).

Natomiast analizując zjawisko terroryzmu można koncentrować się na trzech wspólnych elementach: (1) gwałtownej taktyce działania, opartej na stosowaniu przemocy (2) przede wszystkim przez aktorów niepaństwowych (3) w celach politycznych (Laqueur, 1987, s. 11; Wojciechowski, 2017, s. 21-28). Elementy te stanową podstawę dla studiów nad terroryzmem. Sam terroryzm, jak i studia nad jego istotą oraz przejawami są pełne sprzeczności, wzajemnie wykluczających się wyjątków oraz niepełnych ujęć. Konsensus odnośnie definiowania terroryzmu i jasnego rozgraniczenia go od innych form przemocy, jak dotychczas nie został osiagnięty.

\section{W kręgu postpozytywizmu - teoria feministyczna}

Podstawowym założeniem niniejszego artykułu jest skonstatowanie, że w naukach społecznych dominują dwie główne filozofie (modele) badań, a mianowicie pozytywizm i postpozytywizm. Główne założenie pozytywizmu opiera się na uznaniu, że badacz funkcjonuje poza przedmiotem badania i stosując metody właściwe naukom ścisłym jest w stanie badane zjawisko skutecznie wyjaśnić oraz sformułować prawa rządzące badaną rzeczywistością. Pozytywizm zakłada więc, że zjawiska społeczne i polityczne można badać tak jak w naukach przyrodniczych, czyli metodami nauk ścisłych. Wiara w pozy- 
tywizm, sięga do filozofii Augusta Comte'a (1798-1857). Piszący później inny socjolog francuski, Emile Durkheim (1858-1917), wskazywał, że „fakty społeczne trzeba badać tak jak rzeczy". Niezależnie od tego co się bada metoda naukowa pozostaje ta sama, czyli opiera się na dążeniu do „obiektywizmu, racjonalizmu i próby wychwytywania powiązań pomiędzy różnymi zjawiskami” (Włoch, 2015, s. 202).

Pozytywizm stanowi rodzaj tradycyjnego podejścia badawczego, które opiera się na racjonalistycznych założeniach przedstawionych w XVII w. przez francuskiego filozofa Kartezjusza (1596-1650). Racjonalizm rozróżnia przedmiot (badania) i podmiot (badający), przy czym obydwa są z definicji niezmienne niezależnie od czasu i miejsca. Pozytywistyczne ujęcie zjawisk politycznych znalazło odzwierciedlenie w pracach piszącego w XX wieku prawnika i politologa Carla Schmitta oraz w części wzorującego się na nim badacza stosunków międzynarodowych Hansa Morgenthau'a. Ten ostatni jest uważany za współtwórcę teorii realizmu politycznego. Próbę zmatematyzowanego podejścia do badania polityki zagranicznej i stosunków międzynarodowych stanowi rozwijający się w latach 40. i 50. XX wieku nurt scjentystyczny, a w nim teoria behawioryzmu (behawioralizmu) (Sałajczyk, 1988).

Natomiast od czasu bezpośrednio następującego po I wojnie światowej zaczynają rozwijać się podejścia postpozytywistyczne, kwestionujące dotychczasowy kanon filozofii nauki oparty na założeniu rozłączności przedmiotu badania i podmiotu badającego oraz o obiektywizmie i racjonalności badań w naukach społecznych. Postpozytywiści nawiązują do tzw. historii uczestniczącej rozwijanej we Francji w XIX wieku oraz do wielkiej socjologii niemieckiej w wydaniu Karola Marksa i Maxa Webera. Od Marksa wzięli założenie, że wiedza naukowa jest elementem nadbudowy społecznej, a więc świadomości kształtowanej przez byt społeczny (bazę ekonomiczna), a od Webera, tezę, że aby coś wyjaśnić, należy najpierw to zinterpretować i zrozumieć (niem. Verstehen). Od tego już krok dzieli badaczy do stwierdzenia, że nie ma wiedzy wolnej od wartości i interesów.

W tym nurcie wykształciła się po I wojnie światowej szkoła frankfurcka (Max Horkheimer, Theodor Adorno). To ci badacze analizując koncepcję Oświecenia, a w niej ideały wolności, emancypacji i postępu doszli do paradoksalnego wniosku, że ideały oświeceniowe uległy skrajnej deformacji i zwróciły się przeciwko samej tej koncepcji. To doprowadziło tych autorów do odrzucenia teorii tradycyjnej i przyjęcia teorii krytycznej, której zadaniem jest stawianie problemów, ukierunkowywanie działań naukowych oraz proponowanie alternatyw. Z kolei wybitny wychowanek szkoły frankfurckiej, Jürgen Habermas, zainspirowany marksizmem, zwracał uwagę na kwestię legitymizowania systemów politycznych przez ludzi. Akcentował znaczenie deliberacji w życiu publicznym, czyli rozwiązywania powstających konfliktów w wyniku dyskusji (Włoch, 2015, s. 204). To wprost budowało zręby teorii krytycznej.

Do rozwoju podejścia postpozytywistycznego przyczynili się dwaj socjologowie Peter L. Berger i Thomas Luckmann, którzy w połowie lat 60 . XX wieku wskazywali, że rzeczywistość społeczna, choć wydaje się obiektywna i wobec nich zewnętrzna, jest tworzona poprzez ludzi, a więc może być traktowana jako forma świadomości (Berger, Luckmann, 1966, s. 61). Jest więc ona konstruktem społecznym, produktem życia społecznego, efektem jego wielokrotnej reinterpretacji, przynależy do tradycji badaczy. Na tej podstawie wyciagnięto wniosek, że rzeczywistość społeczna, polityczna nie istnieje 
samodzielnie, lecz jako intersubiektywna świadomość między ludźmi. Jak pisał na początku lat 90. XX wieku Alexander Wendt - relacje między podmiotem a obiektem badania, w tym także z innymi podmiotami (aktorami), określane są przez znaczenie jakie jest im nadawane. Oznacza to, że stosunki społeczne składają się zasadniczo z myśli i idei, nie zaś z elementów materialnych (Wendt, 1992, s. 396-397). Inni badacze dodawali potem, że istotne dla rozpoznania stosunków społecznych jest badanie znaczeń, języka, znaków, sygnałów, wierzeń, interpretacji, dyskursów, norm i tożsamości badanych podmiotów.

Zdaniem konstruktywistów, podstawowym elementem ideacyjnym (intelektualnym) są intersubiektywne przekonania (idee, koncepcje, założenia itp.), powszechnie podzielane przez ludzi. Właśnie te przekonania tworzą i wyrażają interesy i tożsamości ludzi. Oznacza to, że świat społeczny jest światem ludzkiej świadomości. Stanowi więc sferę intersubiektywną - ma sens dla ludzi, którzy go stworzyli, którzy w nim żyją i którzy go rozumieją, właśnie dlatego, że jest ich wytworem i czują się w nim jak u siebie.

W konstruktywizmie wyodrębnia się kilka nurtów. Upraszczając można dostrzegać w nim dwa podstawowe. Pierwszy uznający dziedzictwo pozytywizmu, który przyznaje, że świat społeczny istnieje realnie, ale o jego istocie decydują znaczenia mu przydawane przez podmioty. Jest to nurt umiarkowany reprezentowany przez badaczy publikujących w USA, Alexandra Wendta i Johna Ruggiego. Drugi szerszy nurt o proweniencji europejskiej koncentruje się na warstwie świadomościowej (ideacyjnej) rzeczywistości społecznej. Jest to nurt typowo postpozytywistyczny, zahaczający o postmodernizm. Reprezentuja go m.in.: Nicholas Onuf, Christian Reus-Smit, Scott Burchill, Thomas RisseKappen. Badacze ci nawiązują przede wszystkim do piśmiennictwa francuskiego filozofa i socjologa Michela Foucaulta (1926-1984). W podejściach postpozytywistycznych dużą popularnością cieszy się także postmodernizm, który nawiązuje przede wszystkim do myśli Foucaulta (Bógdał-Brzezińska, 2015).

Feminizm jako teoria naukowa jest wyodrębniany przede wszystkim ze względu na przedmiot badania. Są nim kobiety, ich role w społeczeństwie, polityce i w stosunkach międzynarodowych. Teoria ta zakłada odmienność cech podmiotowych i zachowań kobiet w społeczeństwie. Feminizm podważa możliwości rzetelnego dostępu do obiektywnej rzeczywistości poprzez wyszczególnienie podmiotu w życiu społecznym (,fragmentacja i rozrzucenie"). W pewien sposób podważa pojęcie tożsamości jako ustalonego i spójnego zjawiska dążąc do przekształcenia wiedzy (Ślęczka, 1999, s. 53).

Należy podkreślić, że feminizm nie jest jednolity, wyróżnić w nim można różne nurty, które często określane są mianem fal. Niektórzy autorzy używają określenia w liczbie mnogiej - teorie feministyczne. Natomiast w punktem wyjścia podejmowanych rozważań przez poszczególnych autorów jest założenie o społecznym skonstruowaniu płci i roli oraz miejsca tej kategorii dla teorii nauk o polityce, a także i praktyki życia publicznego (Gasztold, 2017). Feminizm w ujęciu epistemologicznym może mieścić się zarówno w pozytywizmie, jak i postpozytywizmie. Jednak ze względu na znaczenie, jakie badacze przywiązują do odmienności cech podmiotowych i zachowań społecznych kobiet, a to zależy od przyjętych idei mających wpływ na proces poznania, zaliczany jest do ujęć postpozytywistycznych.

Feminizm przedmiotem badania czyni miejsce i role kobiet w życiu społecznym i politycznym. Jego głównym zamierzeniem jest zarówno wnoszenie wkładu do dyskusji 
naukowej i publicznej, jak i konstruowanie różnych idei oraz strategii działania. Główne przesłanie feminizmu to brak zgody na nierówności społeczne stanowiące pochodną różnic płciowych. Odwołując się do tej idei na przestrzeni kilkudziesięciu lat powstały różne wizje porządku publicznego, teorie społeczno-kulturowe, nurty, filozofie i myśl feministyczna oraz metody działania. W ujęciu Amy G. Mazur, feminizm jest klasycznym przykładem pojęcia spornego, odnoszącego się z jednej strony, do praktyki politycznej ruchów kobiet i stanowisk aktorów spoza tego ruchu, a z drugiej, do historii myśli politycznej i innych epistemologicznych stanowisk (Mazur, 2002, s. 2). Historia ruchu i myśli feministycznej ewaluowała od akcentowania dyskryminacji kobiet w przestrzeni publicznej, społecznej, kulturowej, ekonomicznej do określenia miejsca i roli kobiety w świecie. Współcześnie promowane jest przekonanie o kulturowej wspólnocie obu płci.

Większość nurtów feminizmu przynależy do podejść postpozytywistycznych. Ze względu na krytyczną ocenę porządku społecznego zdominowanego przez mężczyzn i głoszone hasła jego zmiany feminizm jest zaliczany także do teorii krytycznych sięgających do ducha słynnego zdania Karola Marksa, który pisał „Filozofowie rozmaicie tylko interpretowali świat, idzie jednak o to, aby go zmieniać. W nauce anglosaskiej dominuje terminologia «teoria krytyczna», ujmowana jako jedna teoria lub zespół teorii krytycznej" (Nicolson, 1998, s. 113), która/y wyłoniła się w tzw. czwartej debacie interparadygmatycznej w końcu lat 80. XX wieku. Natomiast Jacek Czaputowicz używa określania „teorie krytyczne” na oznaczenie wielu teorii stosunków międzynarodowych. Autor ten chociaż dostrzega, że teorie feministyczne rozwijają się od zakończenia I wojny światowej, zalicza je jednak do teorii krytycznych, podobnie jak socjologię historyczną (Czaputowicz, 2007, s. 383).

Pomimo, iż feminizm jest nurtem zróżnicowanym, w opracowaniach teoretycznych zwykle jest ujmowany wśród podejść postpozytywistycznych, takich jak: konstruktywizm, postmodernizm (poststrukturalizm), teoria krytyczna i teoria zielona (green politics). Koncepcje zaliczane do postpozytywizmu koncentrują się na zagadnieniach epistemologicznych, kwestiach ontologii i języka, jakim posługują się tradycyjne koncepcje teoretyczne, w tym na ekspozycji racjonalności i obiektywnej rzeczywistości. Zamiast postrzegania świata $w$ kategoriach uporządkowanych opozycji (przedmiot-podmiot, porządek-anarchia, ciągłość-zmiana, kobieta-mężczyzna itp.). Postpozytywizm proponuje myślenie uwarunkowane wielopłaszczyznowością kategorii analizowanych przez badacza. Postuluje wobec tego powiązanie przedmiotu badania z podmiotem badającym, zamiast przeciwstawianie ich sobie (Peterson, 1992).

Wiąże się to z odmiennym krytycznym i polemicznym ujęciem realnego świata polityki, jak i dekonstrukcją dotychczasowych założeń i podejść badawczych, w których badacze sytuują siebie nie poza przedmiotem badania, ale w jego ramach. Koncepcje feministyczne zyskały popularność głównie wśród badaczy anglosaskich. Potwierdzeniem tego są nie tylko debaty naukowe, ośrodki badawcze, monografie, publikacje zbiorowe, czasopisma wydawane w przede wszystkim w Stanach Zjednoczonych i Wielkiej Brytanii, ale także programy nauczania, które również przyjęły się w Europie kontynentalnej, chociażby w Niemczech i Austrii.

Wyróżniane są cztery nurty myśli postpozytywistycznej. Pierwszy związany jest z teorią krytyczną (podawaną w liczbie pojedynczej) i szkołą frankfurcką. Szczególnie eksponowane są prace Jürgena Habermasa, głównie ze względu na zawartą w nich krytykę po- 
zytywizmu i wskazywanie na nieistnienie wiedzy neutralnej (Habermas, 1985). W jego ujęciu należy rozpatrywać tę wiedzę zawsze w odniesieniu do określonego kontekstu interesów. Z kolei drugi nurt, określany mianem socjologii historycznej, z czołowymi przedstawicielami Michaelem Mannem, Charlesem Tillym, Thedą Skocpol, koncentruje się na genezie oraz istocie państwa i jego przeobrażeniach, które są wynikiem interakcji pomiędzy siłami wewnętrznymi i otoczeniem zewnętrznym (Mann, 2005; Tilly, 2006; Skocpol, 1984), a nie tylko, jak zakładali zwłaszcza neorealiści (np. Kenneth Waltz), efektem oddziaływania otoczenia zewnętrznego. Koncepcje feministyczne zaliczane są do trzeciego nurtu. Wymieniane są w nim zarówno prace autorów koncentrujących się zarówno na kwestiach dotyczących kobiet, jak i aspektach męskiej dominacji oraz badaniach nad płcią i tożsamością. W pierwszej kolejności należy odwołać się do prac Cynthii Enloe, Jean Elshtain, V. Spike Peterson i Anne Sisson Runyan oraz Christine Sylvester (Enloe, 1989; Elsthain, 1987; Peterson, Runyan, 1999; Sylvester, 1994). Do czwartego nurtu można zaliczyć prace postmodernistów (nazywanych także poststruktualistami) Richarda K. Ashleya i Roba B. J. Walkera, Jamesa Der Deriana oraz Michaela J. Shapiro, którzy - nawiązując do dziedzictwa myślicieli francuskich Pierre'a Bourdieu, Michela Foucaulta i Jacquesa Derridy - w swoich badaniach krytykują racjonalizm Oświecenia i przekonanie o możliwości poznania obiektywnej prawdy, gdyż ich zdaniem zawsze badacz jest uwikłany w procesie poznania. Podejmują krytykę paradygmatu szkoły realistycznej szczególnie na gruncie nauki o stosunkach międzynarodowych (Ashley, 1998; Walker, 1993; Der Derian, 1987). Między innymi kwestionują koncept suwerenności państwa oraz stoją na stanowisku, że nie da się zdefiniować i określić granic dyscyplin zajmujących się studiami nad polityka. Granice te są tworem społecznym, a w związku z tym można je stale przekraczać (czyli dekonstruować). Tworzenie jakichkolwiek teorii całościowych, zmierzających do wypracowania uogólnień mających zastosowanie do dalszych rozważań i badań jest bezcelowe w tym ujęciu, gdyż struktura rzeczywistości jest umowna, tak samo jak prawda (Linklater, 1992, s. 88). Kluczem może być jednak język, symbolika i przypisane znaczenia, alternatywność rozwiązań i szerokie spektrum interpretacji. Specyficznymi dla postmodernizmu metodami badawczymi są: ,tekstualność”, dyskurs”, ,gemmologia”, „,dekonstrukcja”, „logocentryzm” (Czaputowicz, 2007, s. 419-427). Stanowisko relatywizmu i subiektywizmu bywa wykorzystane w pozostałych nurtach myśli postpozytywistycznej, takich chociażby jak konstruktywizm czy postmodernizm (Rosenau, 1992).

Ważna dla dalszych rozważań będzie relacja między polityką a przemoca. Przy czym przemoc będzie miała dwoisty charakter: procesu i uwarunkowania, mogąc stać się zarówno „trucizną jak i lekarstwem” współczesnych suwerennych społeczności (Devetak, 1996, s. 194). Problem ten szczególnie da się zaobserwować w debacie nad ograniczeniami wolności na rzecz bezpieczeństwa (doskonałym przykładem jest walka $\mathrm{z}$ terroryzmem) w państwach demokratycznych.

Teoria feminizmu może być wykorzystana do analizy niehomogenicznego zjawiska, jakim jest terroryzm, ze względu na to, że skupia się na badaniach na poziomie jednostki, kobiety i mężczyzny. Różnica płci jako zmiennej konstytuującej rzeczywistość społeczną ma kluczowe znaczenie w studiach nad przemocą polityczną.

Przystępując do omawiania poszczególnych kwestii związanych z teorią feminizmu, należy odnieść się do pojęcia gender. Termin gender (w odróżnieniu od słowa sex) wy- 
korzystywany jest w ukazaniu problemu rodzaju/płci i nierówności z tym związanych. Pojęcie to oznacza „ukształtowany kulturowo zespół atrybutów i zachowań przydanych kobiecie i mężczyźnie" (Humm, 1993, s. 164; Encyklopedia gender, 2014, s. 155-158) i wyraża się poprzez społeczne konstrukcje „męskości” oraz „kobiecości” oparte na antagonizmach, jak np. silny/słaba, władczy/uległa itp. Gender to przypisany przez kulturę mężczyźnie lub kobiecie zespół atrybutów, postaw, ról społecznych i zachowań. Dotyczy cech nabytych. Natomiast sex - to zespół cech wrodzonych, takich jak anatomiczne narządy płciowe, chromosomy (allosomy) i hormony płciowe. Termin gender nie jest zatem pochodny sex, choć tradycyjnie (kulturowo) różnice między mężczyzną a kobietą uznawane są za naturalną konsekwencję biologii. Powiązanie to jest arbitralne i sztuczne. W istocie pod pojęciem gender kryją się konstrukty społeczne i psychologiczne, a nie fizyczne właściwości. Różnice fizyczne pomiędzy obiema płciami mają znaczenie, gdy nadany im jest kontekst sytuacyjny. W języku polskim używa się wyrażeń „płeć kulturowa” (gender) i „płeć biologiczna” (sex).

Płeć biologiczna (sex) może być (a w ujęciu Kate Millett jest) statusem o implikacjach politycznych, gdyż sprowadza się do relacji dominacji i podporządkowania oraz określa zjawisko panowania (niem. Herrschaft) w rozumieniu Maxa Webera (Millett, 2005, s. 38). Należy wyjaśnić, że w języku niemieckim słowo określające władze/panowanie to die Herrschaft pochodzące od rzeczownika der Herr oznaczając mężczyznę, pana, władcę i Boga. Die Frau ma trzy znaczenia: kobieta, żona, pani. Jednak, do używania określenia stanu posiadania np. własności używa się rzeczownika męskiego z żeńską końcówką die Herrin, zrównującego kobietę z mężczyzną/władcą. W wybitny sposób ukazuje to utrwaloną przez język patriarchalną mentalność społeczeństwa. Relacje oparte na dominacji mężczyzny w strukturach społecznych, sprzyjają zjawiskom dyskryminacyjnym wobec kobiet. Męskie panowanie, któremu towarzyszy seksizm, pozostawia pewne sfery wolności dla kobiet. Można to zaobserwować szczególnie w państwach kapitalistycznych. Choć zdaniem czarnych feministek jest to równouprawnienie pozorne, zarezerwowane wyłącznie dla „rasy panującej”, czyli przede wszystkim białych kobiet (bell hooks, 2013, s. 34-39).

Stosowane w niniejszym artykule pojęcie płci odnosi się do różnic między kobietami a mężczyznami, jakie występują w życiu społecznym i politycznym oraz są ich wytworem. W takim ujęciu termin ten rozumiany jest, jako płeć kulturowa w odróżnieniu od płci biologicznej, w której występują różnice nieusuwalne i nienarzucone, wynikające z uwarunkowań fizycznych. Pojęcie gender warunkowane zatem jest przez stereotypy, role, zachowania przyjmowane przez kobiety i mężczyzn w konkretnym przedziale historycznym i w danej kulturze, języku oraz kręgu cywilizacyjnym. Utrwalane jest w procesie socjalizacji. Jest to zatem element osobowości i działań wyuczonych. Tworzy swoistą nadbudowę do tego co biologiczne. Zdaniem Anny Titkow podstawową funkcją kategorii gender jest artykulacja społecznej organizacji różnic płci (Titkow, 2007, s. 28).

\section{Problem przestępczości kobiet}

Mężczyźni i kobiety popełniają przestępstwa przeciwko życiu i zdrowiu zazwyczaj zgodnie z pełnionymi rolami w społeczeństwie. O wiele częściej mężczyzna zabija osoby 
obce, natomiast kobieta bliskie, jak partnera czy dziecko. Rzadko jednak kobiety pozbawiajążycia swoje partnerki, będąc w związku homoseksualnym. Funkcjonuje powszechnie utarte przypuszczenie, że jeśli mężczyzna został zabity przez kobietę, najprawdopodobniej jest to jego żona. Tendencje te nie generalizują uwarunkowań psychologicznych, lecz uwypuklają problemy społeczne, jak np. przemoc w rodzinie (Majchrzyk, 2009, s. 62-63). Wkład w badania w tym zakresie i upowszechnienie problematyki patologii społecznych wniosły przede wszystkim radykalne feministki. Wydobywały one na światło dzienne męską przemoc wobec kobiet, będącą konsekwencją kultury patriarchalnej. Winą obarczają również system prawny, który w sposób nieumiejętny chroni kobiety i utrwala seksistowskie podejście do kobiety-ofiary (Renzetti, 2013, s. 39-42). Na kanwie feminizmu lat 70. XX w. rozwinęła się tzw. feministyczna szkoła kryminologii (kryminologia feministyczna), która zdominowała wcześniejsze dwa nurty rozważań o kobietach i przestępczości - mianowicie nurt biologiczny oraz socjologiczny (Mukherjee, Scutt, 2016; Naffine, 2016; Nowicka, 2017, s. 17-21).

Dorobek kryminologii przeważył w postrzeganiu działalności przestępczej kobiet, w tym terroryzmu. W XIX wieku dotyczyła ona przede wszystkim takich przestępstw jak: przerywanie ciąży, dzieciobójstwo, porzucanie dziecka, kradzież, oszustwo, paserstwo, nieumyślne podpalenie, zniesławienie, składanie fałszywych zeznań, niekiedy zabójstwo, głównie przez otrucie. Studia kryminologiczne zdominowane zostały na kilkadziesiąt lat przez „męskie spojrzenie” Cesare Lombroso. Mniejszy udział kobiet w przestępczości Cesare Lombroso i Gugielmo Ferrero [La donna delinquente, la prostituta e la donna normale, Turin/Rome 1893] przypisywali ich „wyższej” moralności, czystości obyczajów wstrzemię́liwości i religijności. Autorzy podkreślali pozytywne i stereotypowe cechy kobiety powszechnie replikowane przez kulturę. Lombroso nie wykluczał jednak istnienia kobiet-zbrodniarek. Kierując się determinizmem biologicznym uznał, że przestępczynią można było się urodzić. Rozwój jednostki uwarunkowany jest płcią i rasą. Najwyżej w tej hierarchii znajdował się biały mężczyzna, najniżej kobieta kolorowa. Zdaniem Lombroso kobieta bliska jest przestępcy, gdyż reprezentuje wiele cech dzikusa i dziecka (mała waga, niewielki wzrost, słabsze owłosienie, anomalie czaszki i fizjonomii). Kobieta pozostająca w stadium rozwoju dziecięcego (fizycznie i psychicznie) nie predestynowana jest do zbrodni na równi z tymi popełnianymi przez mężczyzn. Obszarem działania przestępczego jest głównie prostytucja, kradzieże, oszustwa, dzieciobójstwo, trucicielstwo. Jeśli już występuje zbrodniczość kobiet cechują: okrucieństwo, wzmożony popęd płciowy (erotyzm) i skłonność do rozpusty, namiętność, uczuciowość, czułostkowość, mściwość, nienawiść, chciwość i skapstwo, próżność, religijność, chwiejność charakteru, inteligencja, upór oraz pomysłowość. Dodatkowo kobiety posiadły umiejętności manipulacji i prowokacji, czyniąc je doskonałe w podżeganiu do popełniania przestępstw (Lombroso, 2016).

Kolejną koncepcją która zyskała wielu sympatyków wśród badaczy akademickich - ale także praktyków - była psychoanaliza. Zygmunt Freud podjął próbę psychologicznej analizy udziału kobiet w przestępczości, która wpływała na kryminologię aż do lat 60. XX wieku. Uznał on, że zazdrość i zawiść kobiety o penisa jest źródłem nieprzystosowania, które może prowadzić do przestępczości, rozumianej jako forma dewiacji. Kobieta-przestępca (dewiant) próbuje być mężczyzną. Każda taka próba kończy się niepowodzeniem, stąd staje się neurotyczna. Osobowość kobiety, która cierpi będąc kastratem 
charakteryzuje pasywność, masochizm i narcyzm, niska świadomość moralna, zazdrość, poczucie niższości, chwiejna sprawiedliwość zależna od stanu emocjonalnego. Zazdrość o penisa w niezaburzonym rozwoju przybiera naturalne skutki: 1) dziewczynka uświadamia sobie ranę zadaną jej narcyzmowi, rozwija w sobie bliznę, która przybiera kształt poczucia niższości; 2) gdy dziewczynka zaczyna uświadamiać sobie, że brak penisa nie dotyczy tylko jej, ale całej grupy dziewcząt zaczyna żywić pogardę taką jaką żywią mężczyźni do kobiet; 3) zazdrość o penisa nie dotyczy tylko i wyłącznie genitaliów; 4) zerwanie uczuciowych kontaktów z matką jest następstwem zazdrości, obarcza ją bowiem winą za brak penisa; 5) przemiana dziewczynki w kobietę: przestaje pragnąć penisa, zaczyna pragnąć dziecka najlepiej płci męskiej. Pasywność jest to droga ku normalnej kobiecości. Niekiedy jednak miłość własna jest zgnębiona przez porównywanie się z chłopcami. Zdarza się, że dziewczynka wypiera swoje życzenia seksualne doprowadzając do zahamowań i nerwicy lub rozwijają się w silny kompleks męskości. Polega on na odmowie uznania kastracji i utwierdzaniu się w przekonaniu, że posiada penisa, przybiera to formy męskich zachowań. Freud twierdził, że kobieta ma w niewielkim stopniu wyrobiony zmysł sprawiedliwości. Wpływ na to ma uczucie zazdrości (Freud, 1995, s. 143-154; Irigaray, 2010, s. 29-41). Pragnienie bycia mężczyzną czyni bycie kobietą niepowodzeniem. Doświadczenia małej dziewczynki, która odkrywa fakt, że nie ma dużego wyraźnego członka stygmatyzują całe jej dalsze życie psychiczne (Freud, 2001, s. 274-275). Założenia te ostro skrytykowano w latach późniejszych. Według np. Juliet Mitchell wybitny psychoanalityk dokonał analizy patriarchalnego modelu wchodzenia w społeczeństwo (Mitchell, 1974).

Otto Pollak zmienił antyfeministyczne tendencje w kryminologii. Uznał, że udział kobiet w przestępczości jest proporcjonalny do ich reprezentacji w populacji oraz częstotliwości przestępstw popełnianych przez mężczyzn. Mniejszy udział kobiet w statystykach świadczyć może o tym, że albo popełniają one tylko pewne typy przestępstw, albo popełniane przez nie czyny są trudniejsze do wykrycia, rzadziej zgłaszane do organów ścigania lub łagodniej traktowane przez sądy. Ta ostatnia hipoteza wiąże się $\mathrm{z}$ dominującym stereotypem kobiety jako istoty łagodnej, a tym samym niezdolnej do popełniania np. zbrodni lub popełniającej przestępstwo pod wpływem prowokacji (silne wzburzenie). Problematyczne są też role zamaskowane kobiet w przygotowaniu i popełnianiu zbrodni. Kobiety mając dostęp do żywności w znacznej mierze kradną i truja, a skala tych przestepstw jest zwykle niewykrywalna. Zdaniem Pollaka negatywne cechy kobiet, jak zdolności manipulacyjne, mściwość, kłamliwość, brak autentyczności sprzyjają przestępczości wśród tej grupy. Uważał on, że doświadczenia menstruacji wywołują traumę niestania się mężczyzną (Pollak, 1961). Role kobiece usankcjonowane tradycją i prawem są doskonałą zasłoną dla tego typu działalności. Dyspozycje biologiczne jednak nie wpływają na popełniane przestępstwa. Takie cechy osobowości, jak chwiejność charakteru, pobudliwość emocjonalna mogą sprzyjać czynom zabronionym, jednak są to uwarunkowania psychologiczne. Mogą one odgrywać rolę w tempie procesu radykalizacji do brutalnego ekstremizmu, jednak niekoniecznie być czynnikiem kluczowym (Zięba, 2017).

Kolejnym oryginalnym założeniem było powielanie tezy, że zespół napięcia miesiączkowego (Premenstrual Syndrome, PMS), jako czynnik stresogenny, negatywnie oddziałuje na zasoby odpornościowe i style radzenia sobie ze stresem. Nagły spadek 
progesteronu wpływa na zmienność nastrojów, generując rozdrażnienie i niekiedy agresywne zachowania. Skrajna postać PMS nie jest charakterystyczna u wszystkich kobiet. Badania nie potwierdzaja, że w momencie dokonywania przestępstw kobiety w znacznej mierze są tuż przed miesiączką. Jest to czynnik mający wpływ pośredni na określone reakcje i adaptację do sytuacji konfliktowych i kryzysowych. Na przykład dziennikarze Anne Moir i David Jessel wykazali na grupie 50 skazanych za zbrodnie z użyciem przemocy, że tylko $44 \%$ było w okresie poprzedzającym menstruację. Generalnie publicyści - promujący tezę wzajemnego oddziaływania hormonów i psychiki oraz różnic między płciami - doszli do wniosku, że kobiety chętniej przestrzegają prawa, choć w przypadku ich konfliktu prawo-jednostka angażują się ze zdwojoną siłą na rzecz ochrony jednostki i życia (Moir, Jessel, 1989; Moir, Jessel, 1998). Stąd hipoteza o większym determinizmie kobiet zaangażowanych politycznie. Wpisuje się w nią Freda Adler uznając, że ruch feministyczny w Stanach Zjednoczonych, który popularyzował emancypację w walce o pozycję społeczną wpłynął też na użycie przez kobiety przemocy. Pragnienie sukcesu, władzy wiąże się z demonstracją siły, odrzuceniem słabości, bierności i podporządkowania (Adler, 1975). Trudno jednak potwierdzić tezę, że wyrównywanie szans wpływa na wzrost przestępczości. Zmienna, jaką jest sytuacja społeczna, nie jest czynnikiem warunkującym partycypację $\mathrm{w}$ terroryzmie, ani $\mathrm{w}$ innych formach przestępczości. $\mathrm{Z}$ kolei inna przedstawicielka feminizmu Rita J. Simon uznaje, że coraz większa liczba kobiet znajdujących zatrudnienie poza domem modyfikuje katalog przestępstw przez nie popełnianych. Zmniejsza się liczba zabójstw na rzecz przestępstw bez użycia przemocy na tle ekonomicznym, jak np. przestępstwa białych kołnierzyków (ang. white-colar cri$m e s)$. Przyczyną przestępstw z użyciem przemocy bowiem są tradycyjne role kobiece spychające je w meandry frustracji, zależności i uległości. Lepsze wykształcenie, a tym samym szanse na rynku pracy uwalniają kobiety od bycia wykorzystywaną $\mathrm{i}$ upokorzoną (Simon, 1975, s. 41).

Różnice biologiczne mogą mieć funkcjonalne znaczenie dla działalności grup terrorystycznych. Kobiety ze względu na ich stereotypowe postrzeganie oraz aspekt fizyczności, mogą być wykorzystywane przez organizację. W takich przypadkach, kobieta postrzegana jest jako zakładnik ugrupowania oraz uwarunkowań, które zmusiły ją do udziału w działalności terrorystycznej. Wpływ stereotypów na postrzeganie kobiet funkcjonuje również poza otoczeniem organizacji terrorystycznych oraz umiejętnie jest wykorzystywany w propagandzie i do rekrutacji nowych członków. Dominujący obraz kobiety skrzywdzonej i cierpiącej - szczególnie z regionów objętych konfliktami zbrojnymi lub kryzysami na tle narodowościowym - łagodzi ewentualne oceny terrorystki, usprawiedliwiając moralnie jej działania poprzez pojęcia odwetu i zemsty. Ponadto niedostrzeganie zagrożenia od strony kobiet wpływa na obniżenie efektywności systemów antyterrorystycznych (Bloom, 2011; Cunningham, 2012). Między innymi błędnie zakłada się, że kobiety raczej działają za pośrednictwem zorganizowanej grupy niż w pojedynkę. Jednak, jeśli było to dotychczasową regułą z nielicznymi wyjątkami to nie oznacza, że postępująca radykalizacja społeczeństw, jaką obserwować można chociażby współcześnie w Europie i w USA, nie spowoduje spopularyzowania kategorii indywidualnego zamachowca (,samotnego wilka”) wśród kobiet. Uznać należy za fakt przestępczość (w tym polityczną) kobiet, lecz warto podkreślić za Carol Smart, że nie można analizować tego w oderwaniu od aktywności mężczyzn w tym zakresie (Smart, 1976). 


\section{Terroryzm z udziałem kobiet}

„Dodawanie kobiet” jest nadrzędnym celem zrozumienia zjawiska terroryzmu. Role kobiet posiadają wiele cech wspólnych z tymi pełnionymi przez mężczyzn. Kobiety angażują się na rzecz ugrupowań w różnych nurtach ideowych. Największy ich aktywny udział współcześnie - co się wiąże z postulatami równouprawnienia, ale nie jest celem samym w sobie - jest w terroryzmie lewicowym, w tym ekologicznym zaliczanym do terroryzmu jednej sprawy. Trudno jednak stwierdzić w jakim stopniu kobiety przyczyniają się do „ukrytego" wsparcia, w tym socjalizacji i rekrutacji na rzecz terroryzmu oraz działań propagandowych w organizacjach skrajnie prawicowych. Szczególnym przykładem są organizacje neofaszystowskie, w których często kobiety są wykluczane z działań stricte politycznych, natomiast zaangażowane w całokształt działań pomocniczych. Związane jest to z ideologią promującją określone wzorce oraz postawy oparte na nierówności płci. Ośmieszanie dążeń emancypacyjnych oraz podporządkowanie kobiet mężczyznom ma również miejsce $w$ grupach o podłożu religijnym. $Z$ tym że np. terroryzm islamski wykorzystuje potencjał militarny kobiet.

Wzory życia kobiety i mężczyzny są różne w zależności od kręgu kulturowo-cywilizacyjnego. Przekłada się to na działania przestępcze. Rodzaj, dynamika, motywacja i nasilenie przestępstw terrorystycznych wskazuje na dysproporcję w partycypacji na korzyść mężczyzn. Istotą jednak nie jest skala udziału procentowego, ale zrozumienie odmienności - ukierunkowanej pod względem specyfiki płci - umieszczonej w konkretnym kontekście historycznym, politycznym, ekonomicznym i kulturowym. Również zmiany strukturalne w państwie dotkniętym terroryzmem w percepcji aktywności kobiet przyczyniają się do krystalizowania się nowej wiedzy na ten temat. Pomocne są tu edukacja dla bezpieczeństwa i kampanie społeczne.

Różnice między płciami w reagowaniu na rzeczywistość polityczna, w tym mechanizmy kontroli gniewu i agresji, przekładają się na wybór ścieżki przemocy lub rezygnacji z niej. Dorobek psychologii ewolucyjnej wykazał, że potencjał agresji między płciami jest podobny. Jednak kobiety o wiele częściej wybierają strategie adaptacyjne, prawdopodobnie ze względu na większą świadomość kary. Agresja mężczyzn warunkowana fizycznością, tendencją do ograniczenia odczuwania skruchy i poczucia winy oraz rolami płciowymi utrwalonymi kulturowo (Campbell, 2006; Baron, Richardson, 1994). Mimo, że potencjał agresji jest podobny, to jednak występują różnice w samych zachowaniach agresywnych między kobietami a mężczyznami (Archer, 2004). Kobiety stają się agresywne w konkretnych sytuacjach. Katalizatorem może być na przykład reakcja sprowokowana (Bettencourt, Miller, 1996). Badania nad różnicami płci w działaniach przestępczych wykazały dysproporcje na korzyść mężczyzn, szczególnie pod względem intensywności i skali. Specyfika płci uwidacznia się również w działaniach związanych z radykalną przemocą polityczną. Postępujący wzrost przestępczości kobiet zauważalny jest również w terroryzmie. Niemniej nie jest zjawiskiem nowym. Terroryzm z udziałem kobiet ma długą tradycję, sięgająca XIX wieku i organizacji o podłożu skrajnie lewicowym. Hasła emancypacyjne związane z partycypacją kobiet w przemocy politycznej kontynuowane były w ruchach neolewicowych oraz niektórych narodowowyzwoleńczych XX i XXI wieku. Wpisywały się one w koncepcje anarchistyczno-rewolucyjne, nie będąc celem samym w sobie. Wyzwaniem współczesności jest rozstrzygnięcie, czy 
rekrutacja kobiet przez organizacje dotychczas na nie zamknięte (prawicowe, religijne) ma związek z równouprawnieniem i nowymi rolami społecznymi, czy raczej z potrzebą poprawienia skuteczności działań grupy. Trudności w analizie naukowej stwarza spiskowy i niehomogeniczny charakter terroryzmu oraz różna motywacja członków/członkiń organizacji przestępczych.

Kobiety odgrywają różne role: logistyczne, rekrutacyjne, biorą udział w walce zbrojnej, dokonują zamachów samobójczych, stają na czele grup oraz tworzą zręby ideologiczne organizacji. Typowymi zadaniami są te zaliczane do logistycznych, jak to usługi kurierskie, protektorskie związane z udzielaniem schronienia, odwiedzaniem oskarżonych i skazanych $\mathrm{w}$ aresztach oraz więzieniach (w celu przekazywania informacji), zastawianie pułapek np. poprzez odciaganie uwagi służb bezpieczeństwa (wabienie), eskortowanie zamachowców i urządzeń (np. umieszczonych w wózkach dla dzieci lub udawanych ciążach) do miejsca przeznaczenia. Ale także fałszowanie dokumentów oraz pozyskiwanie funduszy (legalne i nielegalne) na działanie organizacji. Kolejną znamienną jest rola rekruterki i wykorzystanie kontaktów osobistych celem identyfikacji i werbunku nowych członków. Kobiety aktywne są w działaniach propagandowych poprzez tworzenie oraz monitorowanie stron i wiadomości w Internecie oraz pełniąc funkcję „,sumienia” i narracyjną-legendową. Kobieta-terrorystka to także bojownik, zamachowiec-samobójca, konstruktor ładunków wybuchowych. Rola lidera-decydenta sprowadza się do wytyczania i odpowiedzialności za realizację strategii i taktyki organizacji. Charakterystyczne dla organizacji lewicowych jest określanie kierunków rozwoju ugrupowania poprzez wypracowywanie nadbudowy ideologicznej przez kobiety (Cragin, Daly, 2009, s. 24-100; Zięba, 2015, s. 51-61). Nawet jeśli ostatnie kategorie, w większym zakresie zarezerwowane są dla mężczyzn, zmieniają ten obraz takie postacie jak: Ulrike Meinhof (Frakcja Czerwonej Armii, RAF), Adriana Faranda (Czerwone Brygady, BB), Idoia López Riaño (Kraj Basków i Wolność, ETA), Rima Fakhry (Hezbollah), Rachel Pendergaf (Rycerze Ku Klux Klanu, KKK), Mariam Szaripowa (,czarna wdowa” z Dagestanu), Reem Rijashi (Hamas), Thenmozhi Rajaratnam (Tamilskie Tygrysy Wyzwolenia Ilamu, LTTE), Nelly Avila Moreno (Rewolucyjne Siły Zbrojne Kolumbii, FARC).

\section{Konkluzje}

Terroryzm to metoda realizacji celów politycznych przy pomocy przemocy. Bezsprzeczne jest jej wykorzystywanie w głównej mierze przez mężczyzn, jednak aktywną rolę odgrywają w działalności terrorystycznej również kobiety. Stąd eksperci zestawiając męskich i żeńskich członków organizacji terrorystycznych tendencyjnie obierają za wzór męskiego terrorystę. Problematyczna wydaje się tu narracja o terroryzmie odzwierciedlająca patriarchalne relacje. Kobieta spychana jest na pogranicze rozważań nad bezpieczeństwem. Niezależnie od jej mniejszego udziału procentowego w organizacjach i przestępstwach zaliczanych do terrorystycznych powstaje wątpliwość, czy specyfika terroryzmu z udziałem kobiet nie jest wypaczana przez utrwaloną męską dominację w nauce. Nie tylko w naukach o polityce czy naukach o bezpieczeństwie dostrzegalne jest promowanie męskiej wizji świata i historii. 
Celem feminizmu jest przede wszystkim rekonstrukcja obecności kobiet w wielu dziedzinach rzeczywistości społecznej, w tym w przemocy politycznej. Warte naukowego rozpoznania jest także poszerzanie badań nad terroryzmem, poprzez „dodawanie kobiet”. Dotyczy to badania kobiety jako podmiotu i jej doświadczeń, przy jednoczesnym założeniu, że jest ono odmienne od doświadczeń mężczyzn. Uwarunkowania społeczne i polityczne mogą się różnić, ze względu właśnie na role płciowe i przypisane im znaczenia. Priorytetem powinno więc być dążenie do uwzględnienia kobiet jako obiektu analizy oraz gender jako zmiennej. Płcie oddziałują na siebie nawzajem, są relacyjne, wobec tego obecność kobiet w terroryzmie wpływa na męskie role i zachowania. Wyzwanie, jakim jest badanie transformowania się organizacji terrorystycznych, np. dotychczas zamkniętej na uczestnictwo kobiet, może być kluczowe dla rozwoju studiów nad bezpieczeństwem. Próby wykazania, że główną inspiracją do angażowania się w terroryzm jest dążenie do równouprawnienia płci jest trudne do potwierdzenia, bez rzetelnych badań ilościowych.

Podsumowując można stwierdzić, że kobiety są obecne w organizacjach terrorystycznych i dlatego ich udział winien być badany. Członkostwo kobiet jest zdywersyfikowane pod względem pełnionych ról i wykonywanych zadań, podobnie jak męskich członków tych ugrupowań. Ze względu na szczególne predyspozycje kobiet do budowania sieci społecznych i kulturowo utrwalone role wykorzystywane są w działaniach rekrutacyjnych i logistycznych oraz wywiadowczych. Organizacje terrorystyczne wykorzystują kobiety w działaniach operacyjnych ze względu na skuteczność i propagandę ukierunkowaną na wywołanie współczucia.

\section{Bibliografia}

Adler F. (1975), Sisters in Crime: The Rise of the New Female Criminal, McGraw-Hill, New York.

Archer J. (2004), Sex Differences in Aggression in Real-World Settings: A Meta-Analytic Review, „Review of General Psychology", vol. 8, no. 4.

Ashley R. K. (1998), Untying the Sovereign State: A Double Reading of the Anarchy Problematique, „Millennium: Journal of International Studies”, vol. 17, no. 2.

Baron R. A., Richardson D. R. (red.), (1994), Human Aggression, 2. wyd., Plenum Press, New York.

bell hooks [Watkins G.] (2013), Teoria feministyczna: od marginesu do centrum, przeł. E. Majewska, Wydawnictwo Krytyki Politycznej, Warszawa.

Berger P. L., Luckmann T. L. (1966), The Social Construction of Reality: A Treatise in the Sociology of Knowledge, Doubleday Garden City (N.Y).

Bettencourt B., Miller N. (1996), Gender Differences in Aggression as a Function of Provocation. A Meta-Analysis, „Psychological Bulletin”, vol. 119, no. 3.

Bloom M. (2011), Bombshell: The Many Faces of Women Terrorism, Hurts, London.

Bógdał-Brzezińska A. (2015), Postmodernizm, w: Teorie i podejścia badawcze w nauce o stosunkach międzynarodowych, red. R. Zięba, S. Bieleń, J. Zając, WDiNP UW, Warszawa.

Campbell A. (2006), Sex Differences in Aggression: What are the psychological mediators?, „Aggression and Violent Behavior", vol. 11, no. 3.

Cragin R. K., Daly S. A. (2009), Women as Terrorists: Mothers, Recruiters and Martyrs, Praeger Security International, Santa Barbara-Denver-Oxford.

Cunningham K. J. (2012), Countering Female Terrorism, w: Terrorism Studies: A Reader, red. J. Horgan, K. Braddock, Routledge, London-New York. 
Czaputowicz J. (2007), Teorie stosunków międzynarodowych. Krytyka i systematyzacja, PWN, Warszawa.

Der Derian J. (1987), On Diplomacy: a Genealogy of Western Estrangement, Blackwell, Oxford.

Devetak R. (1996), Postmodernism, w: Theories of International Relations, red. S. Burchill, A. Linklater (i in.), Macmillan Press Ltd, New York.

Elsthain J. B. (1987), Women and War, Basic Books, New York.

Encyklopedia gender. Płeć w kulturze (2014), red. M. Rudaś-Grodzka (i in.), Wydawnictwo Czarna Owca, Warszawa.

Enloe C. (1989), Bananas, Beaches and Bases: Making Feminist Sense of International Politics, Pandora Books, London.

Freud Z. (2001), Wykład XX Życie seksualne człowieka, w: Wstęp do psychoanalizy, Z. Freud, przekł. dr S. Kempnerówny, dr W. Zaniewickiego, De Agostino, Altaya, Warszawa.

Freud Z. (1995), Wykład XXXIII Kobiecość, w: Wykłady ze wstępu do psychoanalizy: Nowy cykl, red. Z. Freud, thum. P. Dybel, Wydawnictwo KR, Warszawa.

Gasztold A. (2017), Teorie feministyczne w naukach o polityce, Kwartalnik Naukowy OAP "e-Politikon" 2017, nr 22.

Gibbs J. P. (1989), Conceptualization of Terrorism, „American Sociological Review”, vol. 54, no. 3.

Habermas J. (1985), Der philosophische Diskurs der Moderne: zwölf Vorlesungen, Surhkamp, Frankfurt am Main [polskie wydanie Filozoficzny dyskurs nowoczesności, przeł. M. Łukasiewicz, Universitas, Kraków 2000].

Humm M. (1993), Stownik teorii feminizmu, Wydawnictwo Naukowe Semper, Warszawa.

Irigaray L. (2010), Ta płeć (jedna) płciq niebędaca, przekł. S. Królak, Wydawnictwo UJ, Kraków.

Jenkins B. M. (1975), International Terrorism. A New Mode of Conflict, w: International Terrorism and World Security, red. D. Carlton, C. Schaerf, Croom Helm, London.

Laqueur W. (1987), The Age of Terrorism, 2 wyd. Little, Brown, Boston.

Linklater A. (1992), The Question of the Next Stage in International Relations Theory: A CriticalTheoretical Point of View, „Millennium: Journal of International Studies”, vol. 21, no. 1.

Lombroso C. (2016), Zbrodniarka urodzona, thum. dr I. Szenhak, Wydawnictwo słowo/obraz/terytoria, Gdańsk.

Majchrzyk Z. (2009), Kiedy kobieta zabija: motywy, osobowość, relacja sprawca-ofiara, strategie obronne. Opinia sqdowo-psychologiczna stanu silnego wzburzenia, UKSW, Warszawa.

Mann M. (2005), Incoherent Empire, Verso, London-New York.

Mazur A. G. (2002), Theorizing Feminist Policy, Oxford University Press, Oxford.

Moir A., Jessel D. (1989), Płeć mózgu: o prawdziwej różnicy między kobieta a mężczyzna, thum. N. Kancewicz-Hoffman, Państwowy Instytut Wydawniczy, Warszawa.

Moir A., Jessel D. (1998), Zbrodnia rodzi się w mózgu. Zagadnienia biologicznych uwarunkowań przestępczości, tłum. H. Jackowska, Książka i Wiedza, Warszawa.

Millett K. (2005), Theory of Sexual Politics, w: Feminist Theory: A Philosophical Anthology, red. A. E. Cud, R. O. Andreasen, Blackwell Publishing, Malden MA.

Mitchell J. (1974), Psychoanalysis and Feminism, Penguin, Harmonsworth-New York.

Mukherjee S. K., Scutt J. A. (red.), (2016), Women and Crime, Routledge Taylor \& Francis Group, London-New York.

Naffine N. (2016), Female Crime: The Construction of Women in Criminology, Routledge Taylor $\&$ Francis Group, London-New York.

Nicolson M. (1998), International Relations: A Concise Introduction, Macmillan, Basingstoke.

Nowicka A. (2017), Partycypacja kobiet w wybranych organizacjach przestępczych, Dom Wydawniczy Elipsa, Warszawa. 
Peterson V. S., Runyan A. S. (1999), Global Gender Issues, II wyd., Westview, Boulder Colorado.

Peterson V. S. (1992), Transgressing Boundaries: Theories of Knowledge, Gender and International Relations, „Millennium: Journal of International Studies”, vol. 21, no. 2.

Pollak O. (1961), Criminality of Women, A. S. Barnes \& Compan, New York.

Renzetti C. M. (2013), Feminist Criminology, Routledge Taylor \& Francis Group, London-New York.

Rosenau P. M. (1992), Post-Modernism and the Social Sciences: Insights, Inroads and Intrusion, Princeton Press, Princeton.

Sałajczyk S. (1988), Nurt scjentystyczny $w$ amerykańskiej nauce o stosunkach międzynarodowych, w: Zmienność i instytucjonalizacja stosunków międzynarodowych, red. J. Kukułka, PWN, Warszawa.

Simon R. J. (1975), Women and Crime, Lexington Books, Mass.

Skocpol Th. (1984), States and Social Revolutions: A Comparative Analysis of France, Russia, and China, Cambridge University Press, Cambridge.

Smart C. (1976), Women, Crime and Criminology: A Feminist Critique, Routledge \& Kegan Paul, Henley-London.

Sylvester Ch. (1994), Feminist Theory and International Relations in the Post-Modern Era, Cambridge University Press, Cambridge.

Ślęczka K. (1999), Feminizm. Ideologie i koncepcje wspótczesnego feminizmu, Wydawnictwo „Książnica", Katowice.

Tilly Ch. (2006), Regimes and Repertoires, The University of Chicago Press, Chicago-London.

Titkow A. (2007), Tożsamość polskich kobiet. Ciagłość - zmiana - konteksty, Wydawnictwo IFiS PAN, Warszawa.

Walker R. B. J. (1993), Inside/Outside: International Relations as Political Theory, Cambridge University Press, Cambridge.

Wendt A. (1992), Anarchy is What States Make of It: The Social Construction of Power Politics, „International Organization", vol. 46, Issue 2.

Wilkinson P. (1996), Inquiry into Legislation Against Terrorism, Report by Lord Loyd of Berwick, vol. 2, Cm 3420, London.

Włoch R. (2015), Teoria krytyczna, w: Teorie $i$ podejścia badawcze $w$ nauce o stosunkach Międzynarodowych, red. R. Zięba, S. Bieleń, J. Zając, WDiNP UW, Warszawa 2015.

Wojciechowski S. (2017), Podstawowe pojęcia i ich znaczenie, w: Zrozumieć współczesny Terroryzm, red. S. Wojciechowski, P. Osiewicz, Difin, Warszawa.

Zięba A. (2017), Radykalizacja kobiet do terroryzmu, w: Bezpieczeństwo antyterrorystyczne. Świadomość społeczna i edukacyjna, red. K. Liedel, P. Piasecka, Difin, Warszawa.

Zięba A. (2015), Problem udziału kobiet w organizacjach terrorystycznych, w: Terroryzm wczoraj i dziś: wybrane problemy, red. P. de la Fuente, W. Gizicki, C. Taracha. Instytut Sądecko-Lubelski, KUL, Lublin.

\section{The feminist perspective on studies on terrorism}

\section{Summary}

The aim of the article is to analyze the problem of terrorism through the prism of assumptions of the diverse theory of feminism, classified as a post-positivist approach. The main assumption of the article is that the study of terrorism using a feminist theory makes it possible to broaden the scope of its analysis and illustrate that this phenomenon has wide cultural, social, and even biological determi- 
nants that shape its genesis, structure, functioning and consequences. The feminist approach facilitates a more comprehensive analysis of the motivation of women to undertake terrorist activities and of how they carry such activities out. By this token, the specificity of female terrorism can be demonstrated. The adopted approach is characteristic of Gender Studies. It focuses on recognizing the differences and similarities between men and women, which are a product of social life. It is assumed that the social status and the roles and potential of women are relational phenomena, which are determined in relation to the status, position and social roles of men. The feminist theory can be used to analyze terrorism, because it focuses the research on the levels of individuals - females and males. The gender difference as a variable constituting social reality is therefore crucial in the study of terrorism. In the conclusion of the article, the author claims that women are members of terrorist organizations and therefore their participation should be examined, and that useful methodology for this purpose has been elaborated by feminist theories.

Key words: studies on terrorism, feminism, gender, postpositivism, female criminality 